\title{
ЗАСТОСУВАННЯ МІСЦЕВОЇ ВАКУУМ-ТЕРАПIÏ В КОМПЛЕКСІ ЛІКУВАННЯ ТРОФІЧНИХ ВИРАЗОК НИЖНІХ КІНЦІВОК, ЗУМОВЛЕНИХ ХРОНІЧНОЮ ВЕНОЗНОЮ НЕДОСТАТНIСТЮ
}

\section{В. І. Лупальцов, С. С. Кітченко \\ Харківский національний медичний університет \\ APPLICATION OF LOCAL VACUUM-THERAPY IN COMPLEX OF TREATMENT OF TROPHIC ULCERS OF THE LOWER EXTREMITIES, CAUSED BY CHRONIC VENOUS INSUFFICIENCY}

\author{
V. I. Lupahltsov, S. S. Kitchenko \\ Kharkiv National Medical University
}

\begin{abstract}
Реферат
Мета дослідження. Поліпшення результатів лікування хворих з приводу трофрічних виразок (ТВ) нижніх кінцівок (НК) венозного генезу шляхом застосування в комплексі лікування місцевої вакуум-терапії (ВT).

Матеріали і методи. Проаналізовані результати лікування 25 хворих, у 13 з яких в коплексі лікування ТВ НК, зумовлених хронічною венозною недостатністю (ХВН), місцево застосовували курси безперервної ВТ протягом 7 - 14 діб, тривалість використання однієї пов'язки 1 - 3 доби, залежно від кількості) ексудату та вираженості мікробного забруднення.

Результати. На тлі застосування ВТ інтенсивність болю в ділянці виразки зменшувалась до $(1,78 \pm 1,32)$ бала наприкінці 2-го тижня лікування, майже в 4 рази прискорювалось очищення ТВ від некротичних мас та фібрину порівняно з таким у контрольній групі, площа ТВ зменшувалась на 78,6\% вже на 14-ту добу лікування. Також швидко зникали перифокальний набряк та гіперемія, через $(6,5 \pm 1,65)$ доби з'являлися грануляції, через $(7,9 \pm 2,2)$ доби - крайова епітелізація. Запально-регенеративний тип цитограм переважав в основній групі вже на 14-ту добу терапії. Швидкість загоєння ТВ в основній групі становила у середньому $(4,6 \pm 0,9) \%$, в групі порівняння - $(2,1 \pm 0,8) \%$, тривалість лікування хворого у стаціонарі зменшилася до $(17,8 \pm 3,0)$ днів. Висновки. Місцеве застосування ВТ в комплексі лікування ТВ НК - достатньо безпечний та ефективний метод, всі пацієнти добре переносили лікування, у них прискорювались очищення виразок, крайова епітелізація, зменшувалась тривалість лікування у стаціонарі.

Ключові слова: хронічна венозна недостатність; трофічні виразки; вакуум-терапія.

Abstract

Objective. Improvement of the treatment results in patients, suffering trophic ulcers (TU) of the lower extremities (LE) of venous genesis, using complex of treatment, including local vacuum-therapy (VTH).

Materials and methods. Results of treatment of 25 patients, in 13 of whom complex of treatment of the LE TU, caused by chronic venous insufficiency ( $\mathrm{CHVI}$ ), were analyzed. The courses of continuous VTH during $7-14$ days were used locally, applying one bandage during $1-3$ days, depending on the exudate quantity and the microbial spoilage severity.

Results. The pain intensity in the ulcer region under influence of the VTH application have reduced to $(1.78 \pm 1.32)$ points at the end of second week of treatment. The TU clearance speed from necrotic masses and fibrin, comparing with control group, was accelerated almost in 4 times, the TU square have reduced by $78.6 \%$ already on the14-th day of treatment. Perifocal oedema and hyperemia quickly disappeared also, in $(6.5 \pm 1.65)$ days granulations has been appeared, and in $(7.9 \pm 2.2)$ days - marginal epithelization. Inflammatoryregenerative type of cytogrammes became dominant in the main group already on the14-th day of therapy. The TU healing speed in the main group was $(4.6 \pm 0.9) \%$ at average, while in the comparison group $-(2.1 \pm 0.8) \%$, the stationary treatment duration have reduced to $(17.8 \pm 3.0)$ days.

Conclusion. Local application of VTH in the TU LE treatment complex is sufficiently safe and effective method, all the patients have had responded to treatment good, in them the ulcers clearance has been accelerated with the edge epithelization, the stationary treatment period reduced.

Keywords: chronic venous insufficiency; trophic ulcers; vacuum-therapy.
\end{abstract}

Частота виявлення ХВН як в Україні, так і в світі має тенденцію до збілышення. Кожного року в економічно розвинених країнах XBН діагностують вперше у 2,6\% жінок та 1,9\% чоловіків [1]. За даними епідеміологічних досліджень, в Україні ХВН виявляють у 26 - 38\% жінок та $10-$ 20\% чоловіків [2]; декомпенсовані та ускладнені форми - у 25 - 46\% пацієнтів [3, 4], що становить 700000 хворих (14,1\% з них віком до 30 років, 57\% - від 31 до 50 років) [5]. На сучасному етапі ефективність лікування ТВ НК венозного генезу за стандартними методиками недостатня (до 10\%), частота рецидиву - до 35\% [6].
Значне поширення ХВН, тенденція до збільшення частоти виникнення 3 ускладненням у вигляді ТВ НК, незадовільні результати як консервативної терапії, так і хірургічного втручання спонукають до пошуку нових та вдосконалення існуючих методів лікування хворих. Сьогодні перспективним методом місцево- 
го лікування ТВ НК вважають застосування негативного тиску - ВТ, що забезпечує очищення виразки, видалення продуктів розпаду тканин, покращення лімфо- та кровообігу, збільшення інтенсивності клітинної проліферації, синтезу основної речовини сполучної тканини та протеїнів $[7,8]$.

Мета дослідження: поліпшення результатів лікування хворих 3 приводу ТВ НК венозного генезу шляхом застосування в комплексі лікуванні місцевої ВТ.

\section{МАТЕРІАЛИ I МЕТОДИ ДОСЛІДЖЕННЯ}

Проаналізовані результати комплексного лікування 25 хворих з приводу ТВ НК флебостатичного генезу, яких лікували в гнійному хірургічному відділенні Харківської міської клінічної лікарні № 31 (клінічна база кафедри хірургії № 3) в період 2016 - 2017 рр. Вік хворих від 30 до 75 років, у середньому $(52 \pm 4,9)$ року, чоловіків - 9 (36\%), жінок - 16 (64\%). В дослідження включені пацієнти, у яких встановлений VI клінічний клас за СЕАР (варикозна хвороба НК в стадії декомпенсації - у 8, посттромбофлебітичний синдром - у 17). Тривалість основного захворювання від 2 до 20 років, тривалість існування ТВ у середньому $(9 \pm 3,6)$ року, площа виразок - від 5 до 26 см² $^{2}$

Пацієнти розподілені на групи: основну - 13 (52\%) та групу порівняння - 12 (48\%) хворих. Об'єктом дослідження були ТВ та особливості перебігу ранового процесу.

Всім хворим проведене комплексне обстеження 3 використанням клінічних, морфологічних та інструментальних методів.

Групи не різнилися за віком пацієнтів та тривалістю основного захворювання. Метою лікування хворих обох групах була підготовка ТВ да аутотрансплантації або створення передумов для спонтанного загоєння. Ефективність ВТ оцінювали на основі аналізу вираженості клінічних проявів патологічного процесу (гіперемія, індурація навколишніх тканин, інтенсивність болю у ТВ), динаміки мікробного забруднення, складу клітин у відбитках з ТВ (на 3, 7, 14-ту та 21-шу добу), тривалості періоду зменшення площі виразки внаслідок крайової епітелізації.
Для ультразвукового кольорового дуплексного сканування вен застосовували апарат ULTIMA PRO 30 3 датчиком 3 частотою 5 - 10 МГц 3 обов'язковим картуванням патологічних змін у венозній системі НК.

Площу ТВ та динаміку іiі змін визначали 3 використанням програми LesionMeter y 1, 7, 9-ту та 14-ту добу: виразку фотографували, на сенсорному екрані пристрою (планшет) обводили краї виразки, за програмою обчислювали площу, дані заносили в обліковий запис пацієнта з метою дослідження в подальшому динаміки ії змін.

Динаміку набряку оцінювали шляхом вимірювання окружності ураженої НК над кісточкою та в нижній третині гомілки до і після лікування за формулою:

$$
\mathrm{MS}=(\mathrm{S}-\mathrm{Sn}) / \mathrm{S} \times \mathrm{t} \times 100,
$$

де MS - відсоток зменшення об'єму гомілки; S - окружність нижньої третини гомілки до лікування, см; Sn - окружність нижньої третини гомілки при повторному вимірюванні, $\mathrm{cm} ; \mathrm{t}$ - період між першим і наступним вимірами, тижнів.

Швидкість епітелізації виразки визначали за формулою:

$\mathrm{DS}=(\mathrm{S}-\mathrm{Sn}) / \mathrm{S} \times \mathrm{t} \times 100$,

де DS - відсоток зменшення площини ТВ; S - площа ТВ до лікування, $\mathrm{CM}^{2} ; \mathrm{Sn}$ - площа ТВ при повторному вимірюванні, $\mathrm{cm}^{2} ; \mathrm{t}$ - період між першим та наступним вимірами, тижнів.

До застосування ВТ та на 3, 7-му добу визначали вид мікрофлори в ТВ за даними бактеріологічного дослідження, а також іiі чутливість до антибактеріальних препаратів методом «дисків» (С. А. Moyer, 1965).

Обчислювали кількість колонієутворювальних одиниць (КУО) в 1 $\mathrm{CM}^{2}$ ранової поверхні - LgКУО/ мл (за C. Baxter, 1973; E. Loeble, 1974 в модифікації М. И. Кузина, Б. М. Костюченка, 1990).

Вираженість больового синдрому визначали за цифровою рейтинговою шкалою (Numerical Rating Scale - NRS) [9].

У пацієнтів основної групи після хірургічної обробки ТВ, що передбачала видалення некротизованих тканин та нашарування фібрину, в комплексі лікування місцево застосовували безперервну ВТ з тиском -125 мм рт. ст. ВТ проводили з використанням апарата HEACO NP32 3 пов'язкою DK10SS курсами по 7 - 14 діб, тривалість використання однієї пов'язки від 1 до 3 діб, залежно від об'єму ексудату та ступеня мікробного забруднення. Пов'язку модифікували відповідно до форми ТВ. В групі порівняння в комплексі лікування місцево застосовували мазі на гідрофільній основі.

\section{РЕЗУЛЬТАТИ \\ TA ÏХ ОБГОВОРЕННЯ}

Інтенсивність болю в основній групі у 1-шу добу становила у середньому $(8,0 \pm 1,64)$ бала, на 6-ту добу - $(6,70 \pm 1,69)$ бала, на 9-ту добу - $(5,33 \pm 1,79)$ бала, на $14-$ ту добу $(1,78 \pm 1,32)$ бала; в групі порівняння вираженість больового синдрому становила у $1-ш у$ добу - $(9,96 \pm 1,43)$ бала, на 6-ту добу - $(8,88 \pm 1,34)$ бала, на 9-ту добу - $(5,25 \pm 1,12)$ бала, на 14-ту добу - $(3,45 \pm 0,93)$ бала.

Очищення ТВ від некротичних мас після застосування ВТ відзначали у середньому через $(4,0 \pm 1,09)$ доби, в групі порівняння - через (16,03 $\pm 6,1$ ) доби.

Площа ТВ за місцевого застосування ВТ на 7, 9-ту та 14-ту добу зменшилася відповідно на 21,9, 36,2 та 78,6\%, в групі порівняння - на 8,8, 10,9 та $17 \%$.

В 11 (84,6\%) хворих основної групи протягом 3 діб відзначали зменшення перифокального набряку та гіперемії, в групі порівняння ці показники зберігалися на 3-тю добу, зникли лише у 4 (33,33\%) хворих на 7-му добу.

В основній групі виділення ранового ексудату зменшилося у 2,39 разу на 5- 6-ту добу. Ріст грануляцій у виразці у хворих основної групи спостерігали через $(6,5 \pm 1,65)$ доби, в групі порівняння - через (9,0 $2,1)$ доби; крайову епітелізацію - відповідно через $(7,9 \pm 2,2)$ та $(9,1 \pm 2,4)$ доби.

За даними цитологічного дослідження, ВТ в основній групі сприяла більш динамічному очищенню ТВ від некрозу та фібрину, зменшенню в цитограмах кількості нейтрофільних гранулоцитів, лімфоцитів, моноцитів - клітин, що відповідають за гостру фазу запалення, та збільшенню кількості макрофагів, фібробластів, полібластів - клітин, відповідальних за репаративні процеси. На 7му добу в основній групі в мазках- 
відбитках в 11 з 13 пацієнтів відзначали III (запальний) тип цитограм, на 14-ту добу у більшості пацієнтів переважав IV (запально-регенеративний) тип цитограм. У хворих групи порівняння таку динаміку цитограм відзначали відповідно на 14-ту та 19 - 21-шу добу.

Концентрація мікроорганізмів у хворих обох груп становила (5,86 \pm 2,79) LgКУО/мл. На 7-му добу в основній групі вона зменшилась до $(2,09 \pm 0,22) \mathrm{LgKУО/мл,} \mathrm{в} \mathrm{групі} \mathrm{порів-}$ няння - до $(5,0 \pm 1,26) \mathrm{LgKУО/мл;} \mathrm{на}$ 14-ту добу - становила відповідно $(1,81 \pm 1,37)$ та $(2,8 \pm 1,19) \mathrm{LgKУО/мЛ.}$

\section{ЛITEPATYPA/REFERENCES}

1. Lishnevskaja VJu. Hronicheskaja venoznaja nedostatochnost: prakticheskie aspekty. Medichna gazeta «Zdorov'ja Ukraïni», 2009.6-7. [In Ukrainian].

2. Hoshchynskyi VB, Luhovyi OB, Piatnychka OZ, Zyma Ila. Aspekty diahnostyky varykoznoho rozshyrennia ven nyzhnikh kintsivok. Ukrainskyi zhurnal khirurhii. 2009;(3):43-5. [In Ukrainian].

3. Shalimov AA, Suharev II. Hirurgija ven. Kiev: Zdorovia; 1984. 256 p. [In Russian].

4. Stojko JuM, Shajdakov EV, Ermakov NA. Kompleksnoe lechenie hronicheskoj venoznoj nedostatochnosti nizhnih konechnostej $\mathrm{V}$ stadii troficheskih rasstrojstv // Consilium medicum. Prilozhenie. 2001;(28):31. [In Russian].

5. Krysa VM, Telemukha SB. Kompleksnyi etapnyi pidkhid v likuvanni venoznykh trofichnykh vyrazok nyzhnikh kintsivok. Klinichna khirurhiia. 2007;(5-6):51-2. [In Ukrainian].
6. Bogdanec LI. Venoznye troficheskie jazvy. Vozmozhnosti sovremennoj flebologii v reshenii staroj problemy. RMZh. Hirurgija. Urologija. 2010;(17):1060-64. [In Russian].

7. Bergan J, Shortell C. Venous ulcers. Paris: Elsevier Academic Press publicaitions; 2007. Section II. Chapter 9: 105-12.

8. Andros G1, Armstrong DG, Attinger CE, Boulton AJ, Frykberg RG Joseph WS, et al. Consensus statement on negative pressure wound therapy (V.A.C. Therapy) for the management of diabetic foot wounds. Vasc Dis Manage. 2006 Jun; Suppl:1-32.

9. Fleischmann W, Strecker W, Bombelli M, Kinzl L. Vacuum sealing as treatment of soft tissue damage in open fractures. Unfallchirurg. 1993;96(9):488-92. 